\title{
MOSNÝ, P. a kol. Nacistické protižidovské zákonodarstvo a stredná Európa.
}

Praha: Leges, 2018, 280 s.

Pracovníci právněhistorického pracoviště trnavské právnické fakulty publikovali výsledky vědecko-výzkumného projektu agentury Vega „Právne postavenie Židov na území Slovenskej republiky v rokoch 1939-1942 so zretel'om na niektoré oblasti právnej úpravy v stredoeurópskom kontexte“", podruhé prostřednictvím pražského nakladatele. V PHS č. 46/2 na stranách 76-99 jsme měli možnost seznámit se s podrobnou studií Kristiny Nevanské Kručayové a Adriany Švecové „Arizácia - negácia práva na vlastníctvo v Slovenskom štátě (1939-1945)“, a tentokrát čtyřčlenný autorský kolektiv předložil práci věnovanou obecné analýze protižidovského zákonodárství na ,území prvej Slovenskej republiky“ s přihlédnutím k protižidovským právním úpravám v Protektorátu Čechy a Morava, Mad’arsku, Polsku a „samozrejme“ v Německu. Autoři v předmluvě konstatují, že primární pozornost věnovali legislativě Slovenského státu, ale zdůraznili skutečnost, že první protižidovský zákon byl v meziválečném období 20. století vydán v Mad’arském království r. 1920 (zák. čl. XXV), které navíc, na rozdíl od dříve uvedeného státu a okupovaných území, bez př́ímého nacistického nátlaku přijalo řadu dalších protižidovských předpisů.

Z obsahu monografie (tak alespoň charakterizoval publikaci její nakladatel v tiráži a autoři v předmluvě) vyplývá, že je tvořena původním textem jen z části (s. 11-73). Údaje o tom, kdo ze spoluautorů (P. Vyšný, Št. Siskovič, J. Lanczová) zpracoval příslušné partie v pěti kapitolách, na něž je publikace rozdělena, uvedeny nejsou.

Převažující část obsahu knížky představuje edice právních předpisů protižidovského zaměření přeložených do slovenštiny (s. 74-273). Největší prostor byl věnován mad'arské normotvorbě (s. 78-190), slovenská část je, oproti očekávání, výrazně menší (s. 191-273), když je navíc do čela předpisů ,slovenské protižidovské legislativy“ zahrnut i česko-slovenský ústavní zmocňovací zákon č. 330/1938 Sb. z 15. prosince 1938 přijatý národním shromážděním republiky Česko-slovenské a publikovaný v jazyku slovenském, jehož účinnost nastala dnem vyhlášení, tj. 17. prosince 1938. Vybraná slovenská legislativa se tak redukuje jen na dvě vládní nařízení, když to časově poslední, tzv. Židovský kodex (č. 198/1941 Sl. z.) pochází z 9. zář́i 1941. Protižidovská normotvorba, jak je obecně známo, byla vydávána i v dalších třech letech. Na ni se však nedostalo. Pokud by se snad vyskytla námitka, že projekt agentury Vega nepřesahuje rok 1942, nelze nalézt důvod, proč nebyl zařazen např. ústavní zákon č. 68/1942 Sl. z., o vystěhování Židů z 15. května 1942, zák. č. 138/1942 Sl. z., zakazující osvojování Židů nebo osvojování Židem, a zák. č. 205/1942 Sl. z., kterým se stanoví způsob likvidace židovských advokátních kanceláří 
i v př́ípadech nepřítomnosti Žida-advokáta. Protižidovská ustanovení obsahuje též (nový) zákon č. 215/1942 S1. z., o HSL'S, v němž se zakazuje členství ve straně Židům a židovským míšencům.

Nelze popřít, že zprrístupnění mad'arských předpisů ve slovenském překladu má pro naprostou většinu českých interesentů o tuto tématiku nepřehlédnutelný význam. Připočítáme-li k nim podrobnější výklad obsahu a účelu zák. čl. XXV/1920, silně omezujícího př́stup mladé židovské populace $\mathrm{k}$ vysokoškolskému vzdělání včetně právnického a limitujícího tak její budoucí uplatnění, a dále část kapitoly o protižidovské úpravě manželství v Mad’arském království, nemluvě o výkladech ilustrujících právní postavení Židů v středověkých monarchiích uherskými př́klady, vychází hungarica jako nejrozsáhlejší část recenzovaného spisu. Německý vklad do tématu představující dílem inspirující vzor, dílem násilně vnucované napodobení je obsažen v kapitole o cestě nacistů k moci a o norimberských zákonech.

Druhorepublikovým a protektorátním poměrům jsou věnovány jen o málo více než dvě strany (44-46). Jejich autor či autorka nevzal(a) dostatečný zřetel na autonomizaci územně zmenšeného státu. Napřs. na s. 44 v úvodu druhého odstavce tvrdí, že až do vzniku protektorátního zrrízení patřily Čechy a Morava do rámce „unitárnej Československej republiky“. Samozřejmě, že dnem nabytí účinnosti zák. č. 299/1938 Sb. z. a n. o udělení autonomie Slovenskej krajine, tj. 23. listopadu 1938, se už o unitární stát nejednalo, když fakticky se o takový útvar nejednalo už od podepsání Žilinské dohody (6. ř́ína 1938) a následného jmenování slovenské krajanské vlády. Obdobně na s. 45 se v druhém odstavci (a opakovaně na s. 46) uvádí, že A. Hitler zrrídil „Protektorátný štátný útvar“, byt’ je všeobecně známo, že jeden pojem vylučuje druhý. Natvrdo řečeno, z pohledu celého dnešního spektra českých autorů protektorát žádným státem nebyl, nehledě na výjimečný, zoufalý dobový pokus tuto kvalitu obhájit, pocházející od dr. J. Hoffmanna, vrchního odborového rady protektorátního ministerstva vnitra. Z textu je rovněž patrné, že autor(ka) neměl(a) přehled ani o struktuře stranického spektra v závěrečných měsících r. 1938. Plyne to alespoň z obratu „,v niektorých vládnych stranách“. Československé vlády od 22. záŕí 1938 nejsou klasickými vládami stranických koalic. Dne 18. listopadu 1938 bylo zveřejněno ustavující provolání Strany národní jednoty (definitivní vznik 30. listopadu 1938), v níž se koncentrovalo celkem 7 dosavadních stran a 18. prosince byla ustavena Národní strana práce vytvořená $\mathrm{v}$ podstatě sloučením dvou předchozích stran. Vládu tedy mohly tvořit nejvýše dvě strany české a členové HSLSS, jak tomu ostatně bylo v případě česko-slovenské vlády jmenované 1 . prosince 1938 prezidentem Háchou. Použití obratu naznačujícího jejich větší počet je proto pro čtenáře zavádějící.

Ani další tvrzení, že vl. nař. č. 379/1938 Sb. z. a n. je v druhorepublikovém zákonodárství první celorepublikovou protižidovskou normou (poslední odstavec na s. 44) není pravdivé. Už vl. nař. č. 219/1938 Sb. z. a n., o dočasných omezeních v živnostenském a jiném výdělečném podnikání a opatření stálého výboru č. 284/1938 Sb. z. a n., o prozatimní úpravě některých otázek týkajících se advokacie, vykazují zřetelnou protižidovskou tendenci.

Větší pozornost si zaslouží konstatování, že židovští lékaři a advokáti „,boli vymazaní“ v souvislosti s nespecifikovaným vládním opatřením protektorátní vlády ze 17. 3. 1939 ze seznamů svých organizací. V r. 2011 a návazně v r. 2017 jsme byli podrobně seznámeni s osudem českých židovských advokátů jednak v knize H. Petrů „Zákonné bezpráví“, jednak ve studii J. Drápala „Postup advokátského stavu v českých zemích proti židovským 
advokátům před druhou světovou válkou“ (PHS 46/2). Dne 15. března 1939 byla zastavena praxe židovským advokátům rozhodnutím advokátní komory v Praze a 16. března 1939 rozhodnutím advokátní komory v Brně, což vzala vláda svým usnesením 17 . března na vědomí a rozhodnutí tak potvrdila. K tzv. vymazání ze seznamu advokátů došlo ve většině př́ipadů až během r. 1940 podle vl. nař. č. 136/1940 Sb. z. a n., o právním postavení židů. Dvě procenta z vymazaných mohla být zapsána do seznamu židovských právních zástupců.

V části věnované slovenským poměrům (s. 49-54) se projevuje diferencovanost postojů dnešní slovenské právní historiografie k tamním létům 1938-1945. Citlivost věci lze ostatně registrovat nejen z této publikace, ale z širšího okruhu literatury slovenských autorů publikované v posledním čtvrtstoletí. I autor recenze ji vnímá rovněž prostřednictvím kontaktů se studenty, diplomanty, rigorozanty přijíždějícími do Prahy ze Slovenské republiky, z nichž někteří zvolili pro kvalifikační práce právě židovskou tématiku, z níž je kontroverzní postoj k vlastní národní a státoprávní minulosti a jejímu poválečnému vyústění zvláště dobř̀ patrný.

Výklad je pojat víceméně jako žádost o racionální porozumění dnešních čtenářů pro historicky hlubší antipatii valné části slovenského obyvatelstva vůči židovské komunitě. Vyhlášení samostatné slovenské státnosti je označováno za „legálny a legitímny akt““. Soudní postih slovenských státních funkcionářů v poválečných letech je ponechán bez povšimnutí. Objasňující komentář by dnešní zejména mladší čtenář uvítal nejen v prrípadě prezidenta a vůdce $\mathrm{J}$. Tisa, ale $\mathrm{i} v$ př́padech odsouzených funkcionářů a poslanců sněmu Slovenskej krajiny (M. Sokol, K. Mederly), kteří vyhlášení státu připravili a odhlasovali.

Na jedné straně se konstatuje zvýšený politický slovenský nacionalismus s přepotřebnými prvky sebeuvědomovacího patriotismu, ale ve větě následující se dovídáme, že nacionalismus u Slováků přinejmenším neměl kdy vzniknout, protože neměl dostatek „časopriestoru, nemal ani potrebné ekonomické zázemie“. Obdobné myšlenkové ekvilibristiky vrcholí na závěr kapitoly návrhem na přijetí stanoviska, i když převzatého od I. Kamence, že na rozdíl od norimberských zákonů se Židovský kodex nikdy tak důsledně neuplatnil. $\mathrm{S}$ ohledem na počet zahubených slovenských Židů nemůže toto stanovisko vyznít jinak než jako cynické a ospravedlňující účel neplnící. Je jen ke škodě věci, že autor(ka) těchto vět nepřipomenul(a), právě v zájmu objektivity, projevy zpochybňující tvrdost protižidovského postupu, které se objevily koncem r. 1942 (E. Filkorn, J. Hollý) nebo zákony, jimiž se v mírné formě upravovaly nejkřiklavější prohřešky arizačního postupu.

Př́nosem publikace je její ediční část, analytické kapitoly už pro svůj menší rozsah jsou spíše informačního rázu, klíčová komparativní kapitola „Prvky a predpoklady protižidovského zákonodarstva v stredoeuropskom priestore v období II. svetovej vojny“ postrádá nejen širší a hlubší záběr, ale, žel, obsahuje i několik nepřesností přehlížejících dosavadní úroveň poznatků z okruhu tématiky, které je práce věnována.

Vladimír Kindl

doi: 10.14712/2464689X.2019.40 